\title{
EDITORIAL
}

\section{Fixed minimum fluid volume for resuscitation: Con}

\author{
Anders Perner $^{1^{*}}$ and Mervyn Singer ${ }^{2}$
}

๑ 2016 Springer-Verlag Berlin Heidelberg and ESICM

The Surviving Sepsis Campaign guideline recommends a minimum IV fluid volume of $30 \mathrm{ml} / \mathrm{kg}$ body weight during initial fluid resuscitation for patients with septic shock [1]. This document acknowledges the limited evidence supporting this recommendation. No randomised trial has specifically assessed different fluid volumes for initial resuscitation in adults with septic shock. We believe that this recommendation may be challenged for the reasons given below.

\section{Complex circulatory failure in sepsis}

The circulatory failure of patients with early septic shock is often complex with varying degrees of hypovolaemia, vasodilatation, vascular hyporeactivity and myocardial depression [2].

\section{Are all patients with septic shock hypovolaemic?}

In general, patients with early septic shock do not have significant external fluid losses to justify the input of many litres of fluid. The reduced circulating blood volume is more likely to be due to internal compartment shifts from capillary leak and from pooling of blood in the small vessels, so-called unstressed volume [3]. Presently, we cannot quantify these internal 'losses'. It may be more meaningful to ask how many patients with early septic shock improve their circulation in response to fluid? In the three recent early goal-directed therapy trials (ARISE, ProCESS and ProMISe) the use of vasopressors ranged from 46 to $67 \%$ [4] so approximately half responded to fluid alone. In these trials there was, however, significant variability in fluid administered and fewer than $20 \%$ of

\footnotetext{
*Correspondence: anders.perner@regionh.dk

${ }^{1}$ Department of Intensive Care, Rigshospitalet, University of Copenhagen, Copenhagen, Denmark

Full author information is available at the end of the article
}

For a contrasting viewpoint, please go to doi:10.1007/s00134-016-4590-2. patients had both hypotension and hyperlactatemia, which significantly increases mortality risk [5]. Of note, the median volume delivered in the emergency department in the $2.5-3 \mathrm{~h}$ before trial entry was $2.2 \mathrm{l}$; assuming a median body weight of $70 \mathrm{~kg}$, only half actually got the recommended $30 \mathrm{ml} / \mathrm{kg}$ as initial resuscitation. Over the $6 \mathrm{~h}$ after trial entry patients received on average an extra $2.3 \mathrm{l}$, again with wide variation. If patients are not in need of extra fluid, there seems little justification to give it.

\section{Unclear balance between benefits and harms from fluid resuscitation}

Even if the septic patient does improve his/her circulation with fluid alone, benefit may only result if fluid leads to sustained improvements in tissue perfusion and organ function and, ultimately, patient-centred outcomes. Clearly, this will be a function of illness severity plus ongoing fluid losses and compartmental shifts.

The randomised FEAST trial in 3141 African children with fever and an impaired circulation showed increased mortality with a $20-40 \mathrm{ml} / \mathrm{kg}$ fluid bolus given on top of maintenance fluid versus maintenance given alone [6]. This mortality excess appeared to be driven by circulatory failure despite initial improvements in the circulation [7], suggesting the children were compromised by the additional fluid and with no capacity to support them with mechanical ventilation or pressor administration. Other studies in patients with septic shock also suggest harm from excessive fluid; these data arise from both retrospective analyses $[8,9]$ and from CLASSIC, a recent prospective feasibility trial from Scandinavia in which ICU patients were randomly assigned to restriction of resuscitation fluid versus standard care, albeit after an initial $30 \mathrm{ml} / \mathrm{kg}$ of fluids before randomisation [10]. Together with the recently updated systematic review of trials assessing conservative versus liberal fluid strategies in adults with sepsis or ARDS [11], these results indicate

\section{Springer}


potential harm from excess fluid. We do not know at which volume the potential benefit of fluid turns into harm in an individual patient with septic shock; one size cannot fit all so it is more rational to target a meaningful physiological endpoint rather than offer a blanket recommendation of a fixed volume.

\section{Therapeutic alternatives}

Vasodilatation and myocardial depression occur frequently in patients with septic shock. Patients presenting with these phenotypes may benefit from early use of vasopressor or inotropic agents rather than fluids. However a balance needs to be struck against harm induced by catecholamines $[12,13]$, and no high-quality data yet support these approaches. Alternatively, other strategies also warrant investigation including corticosteroids, avoidance of excess sedation, and even beta-adrenergic blockade, which all may improve the circulatory status in selected patients. A careful "watchful waiting" conservative approach may also be indicated in patients with hypotension yet maintained organ perfusion.

In any case, a therapeutic strategy based on the patient's history, a thorough clinical examination and, in selected patients, more advanced haemodynamic monitoring will better identify those who will benefit from fluids, vasopressors or inotropes. Many patients with early septic shock are likely to improve with fluid alone. However, using $250-500 \mathrm{ml}$ boluses followed by regular reassessments of the circulation constitutes a reasonable protocol, as some patients will be harmed from too much fluid. This individualised approach is likely to be superior to the fixed volume approach as long as the latter has not been proven to benefit the majority of patients with early septic shock in trials with low risk of bias.

\footnotetext{
Author details

${ }^{1}$ Department of Intensive Care, Rigshospitalet, University of Copenhagen, Copenhagen, Denmark. ${ }^{2}$ Division of Medicine, Bloomsbury Institute of Inten-
} sive Care Medicine, University College London, London WC1E 6BT, UK.

\section{Compliance with ethical standards}

\section{Conflicts of interest}

$\mathrm{AP}$ is a member of the steering committee and Danish national investigator of the Sepsis Act vasopressin trial in septic shock sponsored by Ferring Pharmaceuticals; his department is reimbursed for his time. The department also receives research funds from Fresenius Kabi (the EAT-ICU nutrition trial) and CSL Behring (the INSTINCT trial on immunoglobulins for necrotising soft tissue infections, NSTI).

MS was a co-investigator of the UK Department of Health-funded LeoPARDs trial examining the role of levosimendan in septic shock, and Clinical Pl of a multicentre sepsis biomarker study conducted by the UK Ministry of Defence (DSTL). He is Co-PI of a substudy of the EU Innovative Medicines Initiative Combacte-Magnet Program. He sits on advisory boards for Biotest assessing the role of immunoglobulins in septic shock, and Bayer's novel amikacin nebuliser therapy for hospital-acquired pneumonia. He chaired the Data Monitoring Committee for InflaRx's Phase II trial of a novel C5a inhibitor. He sits on an Advisory Board for Deltex Medical (manufacturer of the CardioQ oesophageal Doppler haemodynamic monitor); his University holds shares in the company and his department receives unrestricted grant support. He is also developing a novel tissue oxygen sensor (manufactured by Oxford Optronix) supported by the Wellcome Trust and the UK Department of Health that is shortly to undergo clinical trials.

Received: 27 September 2016 Accepted: 27 September 2016 Published online: 31 October 2016

\section{References}

1. Dellinger RP, Levy MM, Rhodes A, Annane D, Gerlach H, Opal SM, Sevransky JE, Sprung CL, Douglas IS, Jaeschke R, Osborn TM, Nunnally ME, Townsend SR, Reinhart K, Kleinpell RM, Angus DC, Deutschman CS, Machado FR, Rubenfeld GD, Webb S, Beale RJ, Vincent JL, Moreno R (2013) Surviving Sepsis Campaign: international guidelines for management of severe sepsis and septic shock, 2012. Intensive Care Med 39:165-228

2. Bloch A, Berger D, Takala J (2016) Understanding circulatory failure in sepsis. Intensive Care Med. doi:10.1007/s00134-016-4514-1

3. Berlin DA, Bakker J (2014) Understanding venous return. Intensive Care Med 40:1564-1566

4. Angus DC, Barnato AE, Bell D, Bellomo R, Chong CR, Coats TJ, Davies A, Delaney A, Harrison DA, Holdgate A, Howe B, Huang DT, Iwashyna T, Kellum JA, Peake SL, Pike F, Reade MC, Rowan KM, Singer M, Webb SA, Weissfeld LA, Yealy DM, Young JD (2015) A systematic review and meta-analysis of early goal-directed therapy for septic shock: the ARISE, ProCESS and ProMISe Investigators. Intensive Care Med 41:1549-1560

5. Singer M, Deutschman CS, Seymour CW, Shankar-Hari M, Annane D, Bauer M, Bellomo R, Bernard GR, Chiche JD, Coopersmith CM, Hotchkiss RS, Levy MM, Marshall JC, Martin GS, Opal SM, Rubenfeld GD, van der Poll T, Vincent JL, Angus DC (2016) The third international consensus definitions for sepsis and septic shock (Sepsis-3). JAMA 315:801-810

6. Maitland K, Kiguli S, Opoka RO, Engoru C, Olupot-Olupot P, Akech SO, Nyeko R, Mtove G, Reyburn H, Lang T, Brent B, Evans JA, Tibenderana JK, Crawley J, Russell EC, Levin M, Babiker AG, Gibb DM (2011) Mortality after fluid bolus in African children with severe infection. New Engl J Med 364:2483-2495

7. Maitland K, George EC, Evans JA, Kiguli S, Olupot-Olupot P, Akech SO, Opoka RO, Engoru C, Nyeko R, Mtove G, Reyburn H, Brent B, Nteziyaremye J, Mpoya A, Prevatt N, Dambisya CM, Semakula D, Ddungu A, Okuuny V, Wokulira R, Timbwa M, Otii B, Levin M, Crawley J, Babiker AG, Gibb DM (2013) Exploring mechanisms of excess mortality with early fluid resuscitation: insights from the FEAST trial. BMC Med 11:68

8. Boyd JH, Forbes J, Nakada TA, Walley KR, Russell JA (2011) Fluid resuscitation in septic shock: a positive fluid balance and elevated central venous pressure are associated with increased mortality. Crit Care Med 39:259-265

9. Acheampong A, Vincent $J \mathrm{~L}$ (2015) A positive fluid balance is an independent prognostic factor in patients with sepsis. Crit Care 19:251

10. Hjortrup PB, Haase N, Bundgaard H, Thomsen SL, Winding R, Pettila V, Aaen A, Lodahl D, Berthelsen RE, Christensen H, Madsen MB, Winkel P, Wetterslev J, Perner A, The CLASSIC Trial Group, The Scandinavian Critical Care Trials Group (2016) Restricting volumes of resuscitation fluid in adults with septic shock after initial management: the CLASSIC randomised, parallel-group, multicentre feasibility trial. Intensive Care Med. doi:10.1007/s00134-016-4500-7

11. Silversides JA, Major E, Ferguson JF, Mann EM, McAuley DF, Marshall JC, Blackwood B, Fan E (2016) Conservative fluid management or deresuscitation for patients with sepsis or acute respiratory distress syndrome following the resuscitation phase of critical illness: a systematic review and meta-analysis. Intensive Care Med. doi:10.1007/s00134-016-4573-3

12. Dunser MW, Ruokonen E, Pettila V, Ulmer H, Torgersen C, Schmittinger CA, Jakob S, Takala J (2009) Association of arterial blood pressure and vasopressor load with septic shock mortality: a post hoc analysis of a multicenter trial. Crit Care 13:R181

13. Andreis DT, Singer M (2016) Catecholamines for inflammatory shock: a Jekyll-and-Hyde conundrum. Intensive Care Med 42:1387-1397 